\title{
Genetic diversity in seedling populations of Dipterocarpus gracilis in Kecubung Ulolanang Nature Conservation Reserve, Indonesia
}

\author{
NESTY PRATIWI ROMADINI ${ }^{1}$, SAPTO INDRIOKO $^{2, \boldsymbol{v}}$, WIDIYATNO $^{3}$, ENY FARIDAH $^{4}$, \\ YENI W.N. RATNANINGRUM² \\ ${ }^{1}$ Graduate School of Forestry Science, Faculty of Forestry, Universitas Gadjah Mada. Jl. Agro, Bulaksumur, Sleman 555281, Yogyakarta, Indonesia \\ ${ }^{2}$ Laboratory of Forest Tree Improvement, Faculty of Forestry, Universitas Gadjah Mada. Jl. Agro, Bulaksumur, Sleman 555281, Yogyakarta, Indonesia. \\ Tel.: +62-274-512 102 •email: sindrioko@ugm.ac.id \\ ${ }^{3}$ Laboratory of Silviculture, Faculty of Forestry, Universitas Gadjah Mada. Jl. Agro, Bulaksumur, Sleman 555281, Yogyakarta, Indonesia \\ ${ }^{4}$ Laboratory of Plant Physiology, Faculty of Forestry, Universitas Gadjah Mada. Jl. Agro, Bulaksumur, Sleman 555281, Yogyakarta, Indonesia
}

Manuscript received: 28 November 2020. Revision accepted: 2 February 2021.

\begin{abstract}
Romadini NP, Indrioko S, Widiyatno, Faridah E, Ratnaningrum YWN. 2021. Genetic diversity in seedling populations of Dipterocarpus gracilis in Kecubung Ulolanang Nature Conservation Reserve, Indonesia. Biodiversitas 22: 1138-1145. Dipterocarpus gracilis Blume is one of the native Dipterocarpus species in Java Island, Indonesia. It has commercial value as timber (wood) and nontimber forest products (oleoresin). This species has been considered vulnerable following the Red List of Threatened Species criteria by The International Union for Conservation of Nature (IUCN). We aimed to study the genetic diversity and genetic structure of seedlings as the natural regenerating population of Dipterocarpus gracilis Blume in The Kecubung Ulolanang Nature Conservation Reserve, Batang District, Central Java Province, Indonesia. The D. gracilis population in this area is distributed in four zones. We observed a total of 137 juvenile seedlings representing all the zones. Isozyme markers detected the genetic diversity of $D$. gracilis by peroxidase (PRX), esterase (EST), and acid phosphatase (ACP) enzymes. The mean observed heterozygosity of all the zones was lower (Ho=0.078) than expected heterozygosity $\left(\mathrm{H}_{\mathrm{E}}=0.203\right)$. Genetic depletion occurred because of genetic drifts and founder effects due to low parental diversity. The genetic structure of seedlings is similar to the consequence of inbreeding. We conclude that the genetic diversity of $D$. gracilis decreases when mature trees are reduced. This population has essential values in Java Island and should be a priority evaluation in the in-situ and ex-situ conservation of genetic resources.
\end{abstract}

Keywords: Dipterocarpus gracilis, genetic diversity, vulnerable, drift, allozyme

\section{INTRODUCTION}

The Dipterocarpaceae are the emblematic family of tropical rain forests in Southeast Asia and much of the continental South and South-East Asia's seasonally dry forests (Brearley et al. 2016) . The number of dipterocarps species in Asia is the largest among the regions and has 13 genera and 470 species. In Java Island, only five genera and 11 species are found, although the location is very close to Sumatra and Borneo Islands (Sasaki 2006). Dipterocarpus, one of the genera found in Java Island, is an important component of Dipterocarp forest ecosystems, of which 34 species are listed as critically endangered species (Deb et al. 2017). Dipterocarpus gracilis Blume is one of the native Dipterocarpus species on Java Island. As a type with a commercial value as carpentry timber, $D$. gracilis produces oleoresin products due to non-timber forests product. The potential chemical content of oleoresin is used as a medicinal ingredient that could be considered a good alternative for human remedy (Aslam et al. 2015; Fernandes and Maharani 2019).

Generally, Southeast Asian rainforests have been facing pervasive threats and challenges of forest fragmentation by agricultural development, the impacts of a changing climate on forests and the biodiversity and ecosystem services, and the restoration of forests degraded by logging
(Reynolds et al. 2011). In Java Island, D. gracilis exists in the nature conservation reserve and regenerates naturally. In global assessment, this species has been considered vulnerable following the Red List criteria of vulnerable species by The International Union for Conservation of Nature (IUCN) (Ly et al. 2017). But this species is reported as critically endangered in India, and the factor leading to depletion of habitat is degradation/loss (Barik et al. 2018). As a species with a decreasing population, D. gracilis should be explored in terms of climate change that affects natural resources and ecosystem services (Hansen and Phillips 2015).

An important concern for understanding species adaptation and survival in new climates and biological interactions is genetic variation among species (Ratnam et al. 2014; $\mathrm{Ng}$ et al. 2019) . Genetic diversity and genetic differentiation patterns in spatial scales reflect stochastic and environmental impacts linked to viability on key demographic and evolutionary processes e.g. population size, gene flow, adaptive potential (Pavlova et al. 2017). Besides, inbreeding depression can occur at all development stages in dipterocarp species, including seed formation, seed germination, seedling development, and sapling establishment (Tsumura 2011). In the small population, $D$. gracilis probably losing genetic diversity is associated with inbreeding and reducing residual stand 
reproduction. Genetic conservation efforts could be focused on an assessment of genetic diversity.

This research was designed to study the genetic diversity of the seedling population of $D$. gracilis. The genetic evaluation of the natural population-based on a seedling study was conducted in the Dipterocarpaceae population in the tropical rainforest of Southeast Asia, e.g., Shorea leprosula (Widiyatno et al. 2016; Ang et al. 2016) and Parashorea malaanonan (Ang et al. 2016). A preliminary study (Romadini, unpublished data) showed the highest density of seedlings $\left(2.67 \mathrm{ind} / \mathrm{m}^{2}\right)$. The sapling density was lower $\left(0.045 \mathrm{ind} / \mathrm{m}^{2}\right)$ than the seedling density but was higher than the pole density $\left(0.0012 \mathrm{ind} / \mathrm{m}^{2}\right)$. The pole existence was scarce, indicating that accelerated traits were needed to provide a better forest configuration. However, the study to address the genetic diversity of the seedling of a vulnerable species population in a nature conservation reserve is not yet known. This study aimed to evaluate the genetic diversity of the seedling of $D$. gracilis in a small population. We hypothesized that the genetic diversity of the seedling among the population was low as a result of random genetic drift.

\section{MATERIALS AND METHODS}

\section{Study area}

Kecubung Ulolanang Nature Conservation Reserve is a 69.7 ha conservation area located in Subah, Batang District, Central Java Province, Indonesia. The preservation was based on Ministerial Decree of Forestry and Plantation no. 435 / Kpts-II / 1999 dated June 15, 1999 (Ervina and Wasiq 2018) . It is situated within the geographical limits of $06^{\circ} 51^{\prime} 46^{\prime \prime}-007^{\circ} 11^{\prime} 43^{\prime \prime} \mathrm{S}$ and $109^{\circ} 40^{\prime} 19^{\prime \prime}-110^{\circ} 03^{\prime} 06^{\prime \prime} \mathrm{E}$ (Figure 1). The location is classified into B of Schmidt and Ferguson climate types. The $D$. gracilis population in the Kecubung Ulolanang Nature Conservation Reserve is distributed in four zones (Figure 1). The distance between zones exceeds $200-1,300 \mathrm{~m}$ and is located at different altitudes (Table 1).

\section{Procedures}

Sample collection

In July 2018, fresh juvenile leaves from 137 D. gracilis seedlings were collected from randomly chosen individuals. Leaf samples were placed in a tube and frozen in ice packs prior to allozyme extraction and electrophoresis in the laboratory. Distance between the sampled individuals ranged from $2 \mathrm{~m}$ to $30 \mathrm{~m}$, and it was mapped with a Garmin 64S handheld GPS.

Table 1. The location used for sampling Dipterocarpus gracilis from the four zones

\begin{tabular}{lccc}
\hline Zone & $\begin{array}{c}\text { Elevation }(\mathbf{m} \\
\text { asl) }\end{array}$ & $\begin{array}{c}\text { Number of } \\
\text { samples }\end{array}$ & $\begin{array}{c}\text { Number of } \\
\text { mature trees* }\end{array}$ \\
\hline A & $137-200$ & 30 & 30 \\
B & $144-178$ & 49 & 94 \\
C & $154-168$ & 30 & 47 \\
D & $153-156$ & 30 & 2 \\
\hline
\end{tabular}

Note: *mature tree is indicated by diameter at breast height (DBH) of $>20 \mathrm{~cm}$

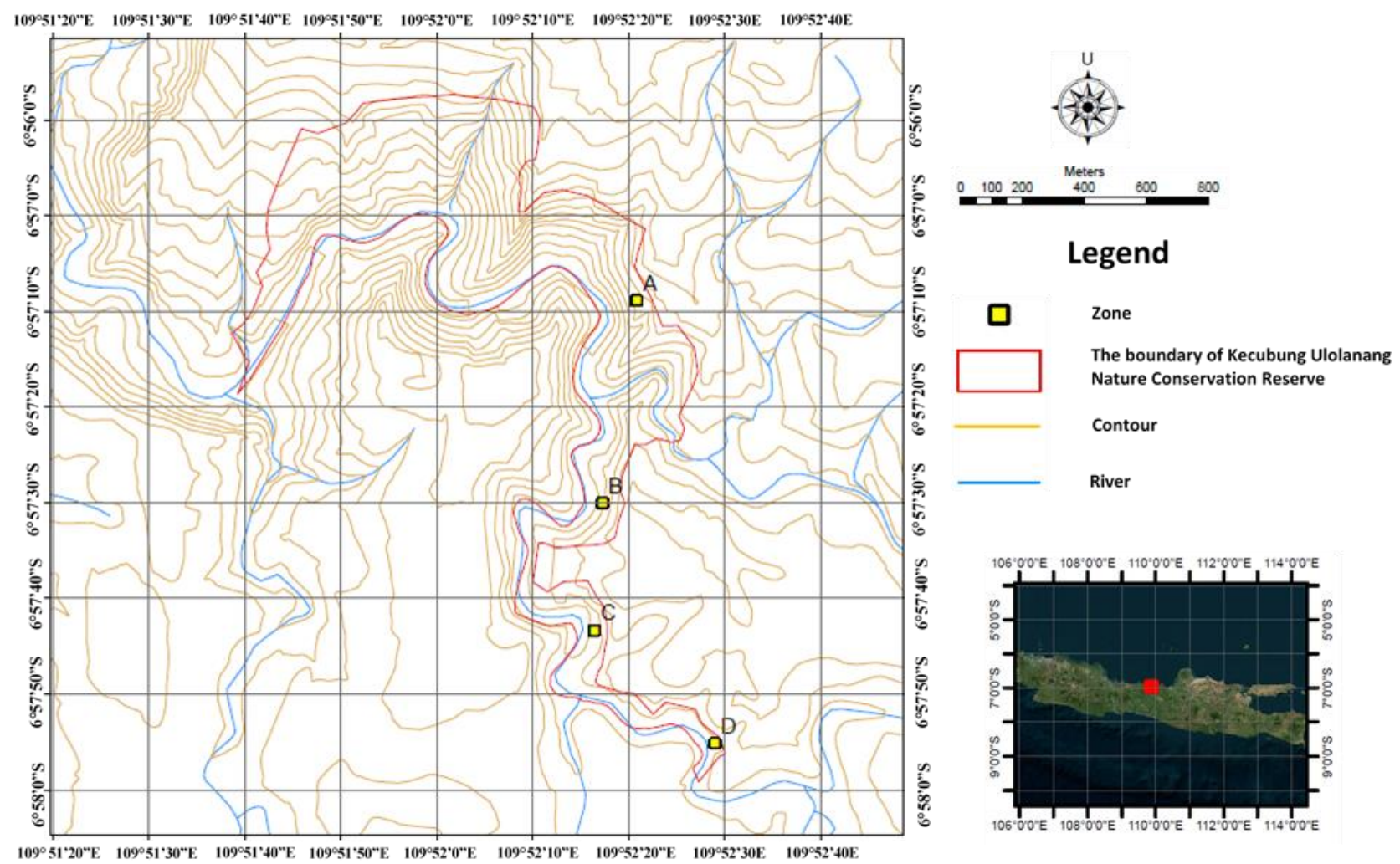

Figure 1. Location of Kecubung Ulolanang Nature Conservation Reserve in Subah, Batang District, Central Java Province, Indonesia 


\section{Isozyme electrophoresis}

Isozyme electrophoresis was conducted with vertical polyacrylamide gel electrophoresis followed by the DavidOrnstein method (Seido 1993). The leaves were homogenized in a modified extraction buffer and centrifuged at $15,000 \mathrm{rpm}$ for $15 \mathrm{~min}$ at $4{ }^{\circ} \mathrm{C}$. The supernatant was loaded onto polyacrylamide vertical slab gels (Sigma Inc., USA) and electrophoresed in a water bath at $4{ }^{\circ} \mathrm{C}, 220 \mathrm{~V}$, and $200 \mathrm{~mA}$ for about 3 hours. After electrophoresis, the gels were stained using a staining solution of each enzyme system. The preliminary analysis screened six enzyme systems, i.e., peroxidase (PRX), shikimate dehydrogenase (SHD), esterase (EST), acid phosphatase (ACP), diaphorase (DIA), and glutamate dehydrogenase (GDH) (unpublished data). Only three enzyme systems, i.e., PRX (E.C. 1.11.1.17.), EST (E.C. 3.1.1.), and ACP (E.C. 3.1.3.2.), produced consistent polymorphic bands, and therefore, were applied to genetic analysis for all samples.

\section{Data analysis}

Genetic diversity

Genetic parameters of the number of alleles per locus $\left(\mathrm{N}_{\mathrm{a}}\right)$, the number of effective alleles $\left(\mathrm{N}_{\mathrm{e}}\right)$ (Kimura and Crow 1964), Shannon's index (I), observed heterozygosity $\left(\mathrm{H}_{\mathrm{O}}\right)$, and expected heterozygosity $\left(\mathrm{H}_{\mathrm{E}}\right)$ were estimated for each zone using GenAlEx 6.5 (Peakall and Smouse 2012). Rare alleles and private alleles were estimated using MS Excel 2010. A bottleneck test was conducted for each population to understand the past population size changes. This analysis was performed under the infinite allele model and the two-phase model using two different tests: the sign test and the Wilcoxon signed-rank test; each test had 1,000 runs in BOTTLENECK 1.2.02 (Cornuet and Luikart 1996).

\section{Genetic structure}

Wright's fixation indices $\left(\mathrm{F}_{\mathrm{IS}}, \mathrm{F}_{\mathrm{IT}}\right.$, and $\left.\mathrm{F}_{\mathrm{ST}}\right)$ were also calculated for four zones using Arlequin 3.5.2.2. POPGENE 1.32 (Yeh et al. 1999) was used to calculate the estimation of Nei's (Nei 1987) to measure population genetic differentiation between the zones and evaluate the genetic relationships among the four zones. A UPGMA dendrogram was created based on Nei's allele frequency and standard genetic distance by using POPGENE 1.32. Data from the four zones were used to test whether the genetic variance was partitioned among the zones using Arlequin 3.5.2.2 (Excoffier and Lischer 2010) for AMOVA.

\section{RESULTS AND DISCUSSION}

\section{Polymorphic loci}

Enzyme systems that showed consistent banding patterns and polymorphisms were PRX, EST, and ACP based on a preliminary study conducted on six enzyme systems (Romadini, unpublished data). The banding patterns were interpreted as the active zone of the enzyme system and interpreted as a locus. Three enzyme systems that produced the genetic diversity and the distribution of allele frequencies are shown in Table 2. The PRX enzyme system could be observed with one locus, i.e., Prx-1 controlled by three alleles. The EST enzyme system could be detected in three loci, namely, Est-1, Est-2, and Est-3 (Table 2). Est-1 was controlled by three alleles, and Est-3 and Est-2 were controlled by two alleles. Although the ACP enzyme system could be observed with only one locus, i.e., Acp-1, which was controlled by three alleles, Acp-1 showed the highest polymorphism in terms of the number of alleles (2.75). Est-2 and Est-3 exhibited the lowest number of alleles (1.25; Table 2). Based on the allele distribution (Table 2), two unique alleles are present in zone A (Est-2-b and Est-3-b) and zone C (Prx-1-c). The presence of unique alleles also indicated that the same alleles were lost in other zones. Prx-1-c alleles presented in zone $\mathrm{C}$ were also rare alleles. Besides, rare alleles were found in other zones, namely, Prx-1-a (Zone A) and Acp-1a (Zone B). Expected heterozygosity $\left(\mathrm{H}_{\mathrm{E}}\right)$ ranged from 0.017 to 0.359 , and the average $H_{E}$ was 0.205 . The alleles that were fixed in this population were Prx-1-c, Est-2-b, and Est-3-b. The expected heterozygosity $\left(\mathrm{H}_{\mathrm{E}}\right)$ and observed heterozygosity $\left(\mathrm{H}_{\mathrm{O}}\right)$ values at each locus are shown in Table 2. The mean $\mathrm{H}_{\mathrm{E}}$ value based on the locus was $0.205(0.031-0.359)$ and the average $\mathrm{H}_{\mathrm{O}}$ was 0.0745 $(0-0.214)$.

\section{Genetic diversity of Dipterocarpus gracilis}

As a key species and one of the Dipterocarps that still occurred naturally in semi-evergreen dry forests on Java Island (Hamilton et al. 2019), the existing D. gracilis population should be maintained. To support forest ecosystem function, the genetic diversity of keystone species is crucial (Ratnam et al. 2014). However, our results showed that genetic drift occurred in this population indicated by the allele fixation and fluctuation of the allele frequency in each locus (Table 2). Oakley and Winn (2012) said that genetic drift in small populations increases both homozygosity within populations and the chance of differentiation among them. These substantiate previous findings in the literature that in small populations, two important genetic mechanisms acting on short to intermediate timescales and threatening are inbreeding depression and increased genetic load due to genetic drift (Pekkala et al. 2014). It was probably caused by a systematic random genetic drift that induced random changes in allele frequencies across zones.

The most striking results (Table 2) were those rare alleles, private alleles, and missing alleles were randomly distributed based on the allele frequencies. The presence of rare and missing alleles suggests that some alleles were not inherited in the next generation (Indrioko and Ratnaningrum 2015). Rare alleles and private alleles were important in this population because these alleles would support the genetic variation. With the loss of rare alleles, genetic variation within a small population can be decreased by random genetic drift and increased homozygosity for common alleles (Gijbels et al. 2015). To maintain its existence, a species requires the ability to survive and adapt, which depends on each individual's genetics. 
Table 2. Distribution of the allele frequencies and genetic diversities of five polymorphic loci from Dipterocarpus gracilis from four zones

\begin{tabular}{|c|c|c|c|c|c|c|c|c|c|}
\hline \multirow{2}{*}{ Locus } & \multirow{2}{*}{ Allele } & \multicolumn{4}{|c|}{ Zone } & \multirow{2}{*}{$\mathbf{N}_{\mathrm{a}}$} & \multirow{2}{*}{$\mathbf{N}_{\mathrm{e}}$} & \multirow{2}{*}{$\mathbf{H}_{\mathbf{O}}$} & \multirow{2}{*}{$\mathbf{H}_{\mathbf{E}}$} \\
\hline & & $\mathbf{A}$ & B & $\mathbf{C}$ & D & & & & \\
\hline \multirow[t]{3}{*}{ Prx-1 } & $\mathrm{a}$ & 0.050 & 0.398 & 0.288 & 0.000 & $2.000 \pm 0.408$ & $1.626 \pm 0.351$ & $0.085 \pm 0.043$ & $0.293 \pm 0.145$ \\
\hline & $\mathrm{b}$ & 0.950 & 0.602 & 0.538 & 1.000 & & & & \\
\hline & c & 0.000 & 0.000 & $0.173^{*}$ & 0.000 & & & & \\
\hline \multirow[t]{3}{*}{ Est-1 } & $\mathrm{a}$ & 0.000 & 0.066 & 0.093 & 0.143 & $2.250 \pm 0.479$ & $1.700 \pm 0.351$ & $0.077 \pm 0.041$ & $0.324 \pm 0.143$ \\
\hline & $\mathrm{b}$ & 0.000 & 0.382 & 0.907 & 0.310 & & & & \\
\hline & $\mathrm{c}$ & 1.000 & 0.553 & 0.000 & 0.548 & & & & \\
\hline \multirow[t]{2}{*}{ Est-2 } & $\mathrm{a}$ & 0.966 & 1.000 & 1.000 & 1.000 & $1.250 \pm 0.250$ & $1.018 \pm 0.018)$ & $0.000 \pm 0.000$ & $0.017 \pm 0.17$ \\
\hline & $\mathrm{b}$ & $0.034^{*}$ & 0.000 & 0.000 & 0.000 & & & & \\
\hline \multirow[t]{2}{*}{ Est-3 } & $\mathrm{a}$ & 0.933 & 1.000 & 1.000 & 1.000 & $1.250 \pm 0.25$ & $1.036 \pm 0.036$ & $0.000 \pm 0.000$ & $0.031 \pm 0.031$ \\
\hline & $\mathrm{b}$ & $0.034^{*}$ & 0.000 & 0.000 & 0.000 & & & & \\
\hline \multirow[t]{3}{*}{ Acp-1 } & $\mathrm{a}$ & 0.017 & 0.024 & 0.104 & 0.000 & $2.750 \pm 0.250$ & $1.608 \pm 0.160$ & $0.214 \pm 0.071$ & $0.359 \pm 0.066$ \\
\hline & $\mathrm{b}$ & 0.586 & 0.786 & 0.750 & 0.897 & & & & \\
\hline & c & 0.397 & 0.190 & 0.146 & 0.103 & & & & \\
\hline Average & & & & & & $1.900 \pm 0.191$ & $1.398 \pm 0.116$ & $0.0745 \pm 0.024$ & $0.205 \pm 0.052$ \\
\hline
\end{tabular}

Note: The standard error of each parameter is shown in parentheses. $*=$ private allele; bold letters $=$ rare allele; the null number in gray background represents the missing allele; $\mathrm{N}_{\mathrm{a}}=$ no. of different alleles; $\mathrm{N}_{\mathrm{e}}=$ no. of effective alleles; $\mathrm{H}_{\mathrm{O}}=$ observed heterozygosity; $\mathrm{H}_{\mathrm{E}}=$ expected heterozygosity

Table 3. Genetic diversity of Dipterocarpus gracilis in the four zones

\begin{tabular}{|c|c|c|c|c|c|c|c|c|c|}
\hline Zone & Number & $\mathbf{N}_{\mathrm{a}}$ & $\mathbf{N}_{\mathrm{e}}$ & $\begin{array}{l}\mathbf{P} \\
(\%)\end{array}$ & I & $\mathbf{H}_{\mathbf{O}}$ & $\mathbf{H}_{\mathrm{E}}$ & $\begin{array}{c}\text { No. of rare } \\
\text { alleles* }\end{array}$ & $\begin{array}{c}\text { No. of private } \\
\text { alleles } * *\end{array}$ \\
\hline $\mathbf{A}$ & 30 & $2(0.32)$ & $\begin{array}{c}1.26 \\
(0.18)\end{array}$ & 80 & $\begin{array}{c}0.27 \\
(0.13)\end{array}$ & $\begin{array}{c}0.05 \\
(0.04)\end{array}$ & $\begin{array}{l}0.16 \\
(0.09)\end{array}$ & $\begin{array}{c}0.31 \\
(0.21)\end{array}$ & $\begin{array}{c}0.40 \\
(0.24)\end{array}$ \\
\hline B & 30 & $2(0.45)$ & $\begin{array}{l}1.53 \\
(0.24)\end{array}$ & 60 & $\begin{array}{c}0.43 \\
(0.18)\end{array}$ & $\begin{array}{c}0.06 \\
(0.02)\end{array}$ & $\begin{array}{c}0.27 \\
(0.12)\end{array}$ & $\begin{array}{c}0.21 \\
(0.21)\end{array}$ & $\begin{array}{c}0.00 \\
(0.00)\end{array}$ \\
\hline C & 47 & $2(0.45)$ & $\begin{array}{c}1.47 \\
(0.28)\end{array}$ & 60 & $\begin{array}{l}0.41 \\
(0.2)\end{array}$ & $\begin{array}{c}0.13 \\
(0.08)\end{array}$ & $\begin{array}{c}0.23 \\
(0.12)\end{array}$ & $\begin{array}{c}0.00 \\
(0.00)\end{array}$ & $\begin{array}{c}0.20 \\
(0.20)\end{array}$ \\
\hline D & 30 & $1.6(0.4)$ & $\begin{array}{c}1.33 \\
(0.27)\end{array}$ & 40 & $\begin{array}{c}0.26 \\
(0.19)\end{array}$ & $\begin{array}{c}0.07 \\
(0.04)\end{array}$ & $\begin{array}{c}0.15 \\
(0.11)\end{array}$ & $\begin{array}{c}0.00 \\
(0.00)\end{array}$ & $\begin{array}{c}0.00 \\
(0.00)\end{array}$ \\
\hline Average & & 1.90 & 1.40 & 60 & 0.34 & 0.078 & 0.203 & & \\
\hline
\end{tabular}

Note: The standard error of each parameter is shown in parentheses. $\mathrm{N}_{\mathrm{a}}=$ allele numbers per locus/observed number of alleles; $\mathrm{N}_{\mathrm{e}}=$ effective number of alleles (Kimura and Crow, 1964) ; I = Shannon's information index; $\mathrm{H}_{\mathrm{E}}=$ expected heterozygosity; *) allele frequency $0.05 ; * *)$ alleles that are found only in a single population among a collection of populations.

In all zones, the mean of the effective alleles per locus $\left(\mathrm{N}_{\mathrm{e}}\right)$ was lower than the number of the allele per locus $\left(\mathrm{N}_{\mathrm{a}}\right.$; Table 3). The mean $\mathrm{N}_{\mathrm{e}}$ was 1.40 (1.26-1.47), with the percentage of polymorphic loci was $40 \%-80 \%$ in each zone. Shannon index in all the zones ranged from 0.26 to 0.43 . The number of mature trees would have affected $\mathrm{N}_{\mathrm{a}}$, $\mathrm{N}_{\mathrm{e}}$, and $\mathrm{I}$. $\mathrm{Na}, \mathrm{Ne}$, and $\mathrm{I}$ in zones $\mathrm{B}$ and $\mathrm{C}$ were higher than those in zones A and D. A high value was probably related to the number of mature trees with the possibility of having a high diversity, which can be passed on to the offspring.

At a population level, the genetic diversity also could be calculated as observed heterozygosity $\left(\mathrm{H}_{\mathrm{O}}\right)$ and expected heterozygosity $\left(\mathrm{H}_{\mathrm{E}}\right)$. Zone $\mathrm{C}$ showed the highest genetic diversity among the four zones. Zone A had the lowest observed heterozygosity value, which implied that the genetic variation in this zone was smaller than the other zones. Generally, the mean $\mathrm{H}_{\mathrm{O}}$ of all the zones was lower (0.078) than $\mathrm{H}_{\mathrm{E}}(0.203)$. Our result is similar to that of another Dipterocarpus study that population size had an affect on the low heterozygosity of D. littoralis (Dwiyanti et al. 2014) . Interestingly, our results were much smaller than the mean $\mathrm{H}_{\mathrm{E}}$ obtained from natural populations with various silvicultural systems (Widiyatno et al. 2016). In this forest management practices study, these parameters were not sensitive because several generations were necessary to determine the effect of reduction in $\mathrm{H}_{\mathrm{E}}$. Ratnam et al. (2014) suggest that expected heterozygosity $\left(\mathrm{H}_{\mathrm{E}}\right)$ is not very sensitive to bottlenecks and perturbations in populations. Therefore, our finding was of significant information because the results showed that the heterozygosity of $D$. gracilis in the Nature Conservation Reserve indicated a decreasing trend. Low genetic variation in a small population is particularly challenging for conservation management. These findings contrast with a goal of conservation management which is to enhance the population's adaptive ability, i.e. the capacity of the population to adapt and survive in the face of environmental changes (Sgrò et al. 2011) .

Extreme drift leads the genetic bottleneck effects and can be detected by changes in allele frequencies. The loss of this allele reduces the ratio, which results in a population bottleneck. In this case, the bottleneck effect analysis 
results revealed that the results were not significantly different in all the zones and possibly did not reflect the founder effect since this plant existed. This finding indicated that the genetic alterations were relatively unchanged from the start. However, the minimal number of individuals and the relatively incompatible flower's pollination and fertilization likely led to the extinction of this species if no effort was devoted to conserving it, especially if a drastic environmental change would trigger a bottleneck effect (Table 4).

\section{Differentiation and genetic structure}

Synchronized flowering effectively promotes successful pollination and mass general flowering events of Dipterocarpaceae species are important for maintaining genetic diversity (Tani et al. 2012) . Generally, the outcrossing rate of Dipterocarpaceae species is high. However, the outcrossing rate appears to be poor in forests with a lower density of mature trees, depending on the key pollinators (Tsumura 2011). The calculated fixation index $\left(F_{I S}\right)$ showed a positive value of 0.6778 which indicates that all populations have a trend to reduce heterozygosity

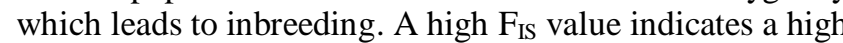
inbreeding as a result of a small and isolated population that can increase deleterious allele fixation (Lynch et al. 1995). F FT showed positive value (0.758). This is also possibly occurred because dipterocarps are not synchronous in the flowering phase, and they pollinate nearby trees that tend to have a high genetic relationship (Widiyatno et al. 2017). Besides, where mature trees are at a low density, it will result in lower outcrossing caused by poorly dispersing pollinators.

The genetic differentiation between individuals was higher $(50.76 \%)$ than that of between zones $(25.1 \%)$ (Table $5)$, in accordance with the overall $F_{S T}$ value $(0.251)$. The proportion of variation in individuals was $24.1 \%$. F FT was calculated to evaluate the genetic differentiation between zones and had a positive value $(0.251)$, which indicated a very high genetic differentiation within the zone (Hartl and Clark 1997). Strong genetic differentiation in Dipterocarpaceae species (such as $S$. macrophylla), probably associated with short seed dispersal distances and limited habitats (Utomo et al. 2018). Gene flow due to the random movement of living things such as pollinators can reduce genetic differences between populations and increase population variation. Connectivity between zones can still be maintained if the presence of pollinators and seed dispersal processes can still be present. The presence of pollen donors from outside the zone can help to reduce

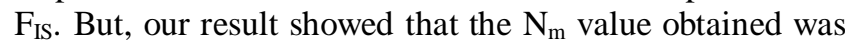
0.746 , resulting from $F_{S T}$ value. $\mathrm{N}_{\mathrm{m}}<1$ values indicate genetic drift as a cause of population differentiation (Slatkin 1987). Similar results were reported in D. alatus (Tam et al. 2014) and D. costasus (Duc et al. 2016), wherein $\mathrm{N}_{\mathrm{m}}$ value was under $1\left(\mathrm{~N}_{\mathrm{m}}<1\right)$ with low genetic diversity which is a consequence of inbreeding within the small and isolated population. This lends support to previous findings in the literature that genetic drift usually decreases the total amount of genetic variation and when spatial structure becomes more pronounced, this effect is comparably stronger for the lower levels of gene flow (Star and Spencer 2013).

The genetic diversity between the zones compared with the genetic diversity between individuals was supported by cluster analysis results. Based on cluster analysis, the four zones of D. gracilis in this nature conservation reserve are divided into two main groups (Figure 2). The first group consisted of Zone A, B, and D. Two sub-group were identified within the first group. Zone $\mathrm{C}$ was grouped into the second sub-group. In this case, genetic and geographical distances did not have a linear relationship. Zones B and D, which were geographically relatively far apart, tend to have proximity compared with zone C (Table $6)$.

Table 4. Results of bottleneck tests on Dipterocarpus gracilis in the four zones under two models of mutation: the infinite allele model (IAM), the three-phase model (TPM), and SMM (with variance $=30$ and probability $=70 \%$ )

\begin{tabular}{cccc}
\hline Zone & IAM & TPM & SMM \\
\hline A & $0.388(0.27)$ & $0.335(0.17)$ & $0.322(0.10)$ \\
B & $0.103(0.04)$ & $0.523(0.09)$ & $0.572(0.20)$ \\
C & $0.485(0.22)$ & $0.460(0.35)$ & $0.408(0.47)$ \\
D & $0.733(0.21)$ & $0.747(0.30)$ & $0.742(0.37)$ \\
\hline
\end{tabular}

Note: The standard error of each parameter is shown in parentheses.

Table 5. Analysis of molecular variance (AMOVA) partitioning of the total genetic diversity within and among the zones

\begin{tabular}{lccc}
\hline Source of variation & $\begin{array}{c}\text { Sum of } \\
\text { square }\end{array}$ & $\begin{array}{c}\text { Variance } \\
\text { components }\end{array}$ & $\begin{array}{c}\text { Percentage } \\
\text { of variation }\end{array}$ \\
\hline Among zone & 34.096 & 0.19447 & 25.104 \\
Among individual & 105.207 & 0.39324 & 50.763 \\
Within individual & 21.500 & 0.18694 & 24.132 \\
Total & 160.803 & 0.77465 & \\
\hline
\end{tabular}

Table 6. Nei's unbiased measure of genetic identity and genetic distance

\begin{tabular}{lllll}
\cline { 1 - 1 } \multicolumn{1}{c}{ Zone } & \multicolumn{1}{c}{$\mathbf{A}$} & \multicolumn{1}{c}{ B } & \multicolumn{1}{c}{ C } & \multicolumn{1}{c}{ D } \\
\cline { 1 - 4 } $\mathrm{A}$ & $* * * *$ & 0.9203 & 0.7340 & 0.9432 \\
$\mathrm{~B}$ & 0.0830 & $* * * *$ & 0.9172 & 0.9606 \\
$\mathrm{C}$ & 0.3093 & 0.0864 & $* * * *$ & 0.8767 \\
$\mathrm{D}$ & 0.0584 & 0.0402 & 0.1315 & $* * * *$ \\
\hline
\end{tabular}

Note: Nei's genetic identity (above diagonal) and genetic distance (below diagonal)

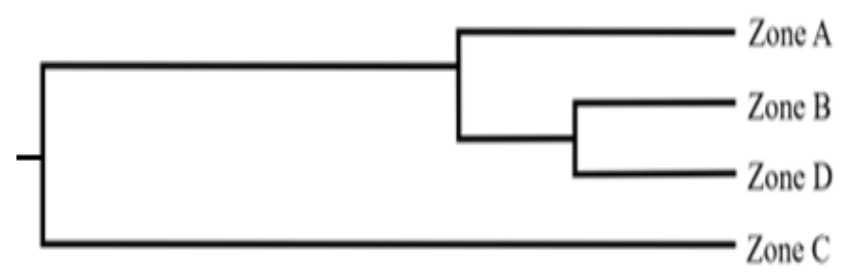

Figure 2. Dendrogram based on Nei's (1978) genetic distance with UPGMA 
While D. gracilis pollinators have not been documented, the donor pollen from outside the zone is possible because pollination on Dipterocarpaceae is generally assisted by insects (Tito de Morais et al. 2015) . The characteristics of $D$. gracilis fruits are winged and easily carried by the wind or gravity and it can be distributed to other zones, although the distribution is not optimal in the process because of disturbances such as the presence of understorey plants. A previous study (Smith et al. 2015) revealedt that seed dispersal distances of Dipterocarpus species such as D. crinitus and D. cornutus is predicted to be $7-11 \mathrm{~m}$. In this study, the large geographical distances between the zones could be the limitation of seed dispersal. Natural boundaries could also be the causes of the emergence of discontinuous populations and often occur in Dipterocarpaceae in natural forests.

In general, the genetic diversity of $D$. gracilis from the four zones in this nature conservation reserve was not suitable due to a decrease in heterozygosity, which is indicated by drift and the tendency to increase in inbreeding. It was similar to Santalum album case in Gunung Sewu (Java Island) with genetic depletion. Heavyexploitation, natural disturbance, genetic drift, bottleneck effect, and founder effect has reduced its genetic diversity (Ratnaningrum et al. 2015). Therefore, large gene flow and broad genetic base are important for maintaining genetical processes (Ratnaningrum et al. 2017). Besides, on Java Island, a large proportion of deforestation was significantly driven by small-scale agriculture (Austin et al. 2019). Based on these conditions, we must pay attention to the genetic resources of Dipterocarpaceae population under various landscape structures, especially on Java Island.

\section{Implications for the sustainable management of tropical rainforests}

As a keystone and potentially lesser-known species, $D$. gracilis should be a priority of evaluation in the in-situ and ex-situ conservation of genetic resources. As generally known that poor integration of genetics and evolutionary biology into conservation planning is a major cause of ineffective forest management (Ralls et al. 2018). The population of Kecubung Ulolanang Nature Conservation Reserve has important values in Java Island, and its management must focus on genetic aspects and be based on a landscape scale. Genetic drift that occurs in this population, the existence of these alleles must be preserved. We suggest the improvement of the connectivity between zones to counterforce declining population size, low genetic diversity, and local extinction (Griffiths et al. 2020) . This implies that management should be conducted not only in the zone where $D$. gracilis are growing but also in the surrounding area as a buffer zone. Areas between zones that are not covered by $D$. gracilis individuals should be enriched to maintain gene flow. Genetic diversity, which is the genetic potential in a population, should be maintained. It is important not only in conserving natural species but also in utilizing breeding materials to increase product utilization value. These study results are considered as the basis for determining the conservation actions that should be taken.

Human intervention can help maintain the genetic potential of the population. Enrichment planting in the population of $D$. gracilis in Kecubung Ulolanang Nature Conservation Reserve is needed to increase genetic diversity and improve conservation to support ecological important species (Millet et al. 2013). But we need a selection of species for enrichment planting that involves native species which is important to maintain the diversity of late succession species (Widiyatno et al. 2020) . Efforts to minimizing the loss of rare alleles can maintain the variation in the population. Besides, the private allele transfer from one zone to another can be performed to increase the genetic diversity of the population across zones. But we also need much attention for seed collecting processes. Finger et al. (2012) suggest that to minimize the likelihood of disrupting any local adaptation, seeds must be collected from donor sites that are not only diverse and outbred but also from similar site conditions.

Individuals from outside the nature conservation reserve can be introduced to increase population diversity. The steps that may be implemented to keep the genetic diversity of $D$. gracilis include maintaining the existence of the population and encouraging the success of natural regeneration. The population quality should be maintained and improved to keep the existence of pollinating agents. Pollinators may contribute to maintaining the diversity of species (Kettle et al. 2011). The reproductive success and continuity of $D$. gracilis generation are determined in terms of the level of the genetic diversity of parents and the success of the interbreeding pattern of living trees (remnant trees). This approach increases the genetic diversity and adaptability of $D$. gracilis in Kecubung Ulolalang Nature Conservation Reserve and in the natural ecosystem of Java Island, whose sustainability contributes to ecological balance and other living things.

\section{ACKNOWLEDGEMENTS}

We appreciate the financial support of the PMDSU Scholarship in 2018 (No.148/SP2H/PTNBH/DRPM/2018 and 5717/UN1.DITLIT/DIT-LIT/LT/2018) from the Ministry of Research, Technology, and Higher Education in this research, which was part of Nesty Pratiwi Romadini's Ph.D. We thank our colleagues from Universitas Gadjah Mada, Yogyakarta, Indonesia and Balai Konservasi Sumberdaya Alam of Central Java, Indonesia, for providing insights and offering their expertise.

\section{REFERENCES}

Ang CC, O’Brien MJ, Ng KKS, Lee PC, Hector A, Schmid B, Shimizu KK. 2016. Genetic diversity of two tropical tree species of the Dipterocarpaceae following logging and restoration in Borneo: high genetic diversity in plots with high species diversity. Plant Ecol Divers 9(5-6): 459-469. DOI: 10.1080/17550874.2016.1270363

Aslam MS, Ahmad MS, Mamat ASOH. 2015. A Phytochemical, ethnomedicinal and pharmacological review of genus Dipterocarpus Intl J Pharm Pharm Sci 7: 27-38. 
Austin KG, Schwantes A, Gu Y, Kasibhatla PS. 2019. What causes deforestation in Indonesia? Environ Res Lett 14 (2): 024007. DOI: 10.1088/1748-9326/aaf6db

Barik SK, Rao BRP, Haridasan K, Adhikari D, Singh PP, Tiwary R. 2018 Classifying threatened species of India using IUCN criteria. Curr Sci 114 (3): 588-595. DOI: 10.18520/cs/v114/i03/588-595

Brearley FQ, Banin LF, Saner P. 2016. The ecology of the Asian dipterocarps. Plant Ecol Divers 9 (5-6): 429-436. DOI: 10.1080/17550874.2017.1285363

Cornuet JM, Luikart G. 1996. Description and power analysis of two tests for detecting recent population bottlenecks from allele frequency data. Genetics 144(4) : 2001-2014. DOI: 10.1093/oxfordjournals.jhered.a111627

Deb JC, Phinn S, Butt N, McAlpine CA. 2017. The impact of climate change on the distribution of two threatened dipterocarp trees. Ecol Evol 7(7) : 2238-2248. DOI: 10.1002/ece3.2846

Duc NM, Duy VD, Xuan BTT, Thang BV, Ha NTH, Tam NM. 2016. Genetic structure of the threatened Dipterocarpus costatus populations in lowland tropical rainforests of Southern Vietnam. Genet Mol Res 15(4) : 1-10. DOI: 10.4238/gmr15048821

Dwiyanti FG, Harada K, Siregar IZ, Kamiya K. 2014. Population genetics of the critically endangered species Dipterocarpus littoralis Blume (Dipterocarpaceae) endemic in Nusakambangan Island, Indonesia. Biotropia 21 (1) : 1-12. DOI: 10.11598/btb.2014.21.1.1

Ervina R, Wasiq HJ. 2018. Vegetation structure of ebony leaf monkey (Trachypithecus auratus) habitat in Kecubung Ulolanang Nature Preservation Central Java-Indonesia. In Hadiyanto, Sudarno, Maryono (Eds). Proceeding of The $2^{\text {nd }}$ International Conference on Energy, Environmental and Information System (ICENIS 2017). Universitas Diponegoro, Semarang 15-16 August 2017. DOI: $10.1051 /$ e3sconf/20183108016

Excoffier L, Lischer HEL. 2010. Arlequin suite ver 3.5: A new series of programs to perform population genetics analyses under Linux and Windows. Mol Ecol Resour 10 (3): 564-567. DOI: 10.1111/j.17550998.2010.02847.x

Fernandes A, Maharani R. 2019. Phytochemical and GC-MS analysis of oleoresin of Dipterocarpus gracilis Blume: As a basic consideration for human remedy. Intl J Pharm Sci Res 10(5) : 2224-29. DOI: 10.13040/IJPSR.0975-8232.10(5).2224-29

Finger A, Kettle, CJ, Kaiser-Bunbury CN, Valentin T, Mougal J, Ghazoul J. 2012. Forest fragmentation genetics in a formerly widespread island endemic tree: Vateriopsis seychellarum (Dipterocarpaceae). Mol Ecol 21(10): 2369-2382. DOI: 10.1111/j.1365294X.2012.05543.X

Gijbels P, De Hert K, Jacquemyn H, Honnay O. 2015. Reduced fecundity and genetic diversity in small populations of rewarding versus deceptive orchid species: A meta-analysis. Plant Ecol Evol 148(2) : 153-159. DOI: 10.5091/plecevo.2015.914

Griffiths SM, Taylor-Cox ED, Behringer DC, Butler MJ, Preziosi RF. 2020. Using genetics to inform restoration and predict resilience in declining populations of a keystone marine sponge. Biodivers Conserv 29(4) : 1383-1410. DOI: 10.1007/s10531-020-01941-7.

Hamilton R, Hall T, Stevenson J, Penny D. 2019. Distinguishing the pollen of Dipterocarpaceae from the seasonally dry and moist tropics of South-east Asia using light microscopy. Rev Palaeobot Palynol 263: 117-133. DOI: 10.1016/j.revpalbo.2019.01.012.

Hansen AJ, Phillips LB. 2015. Which tree species and biome types are most vulnerable to climate change in the US Northern Rocky Mountains?. For Ecol Manag 338: 68-83. DOI: 10.1016/j.foreco.2014.11.008.

Hartl DL. and Clark GC. 1997. Principles of Population Genetics. Sinauer Associates, Sunderland.

Indrioko S, Ratnaningrum YWN. 2015. Habitat loss caused clonality, genetic diversity reduction and reproductive failure in Santalum album (Santalaceae), an endangered endemic species of Indonesia. Proc Environ Sci 5: 613-620. DOI: 10.1016/j.proenv.2015.07.077.

Kettle CJ, Maycock CR, Ghazoul J, Hollingsworth PM, Khoo E, Sukri RSH, Burslem DFRP. 2011. Ecological implications of a flower size/number trade-off in tropical forest trees. PLoS ONE 6 (2). DOI: 10.1371/journal.pone.0016111.

Kimura M, Crow JF. 1964. The number of alleles that can be maintained in a finite population. Genetics 49 (4): 725-738.

Ly V, Nanthavong K, Pooma R, Luu HT, Nguyen HN, Barstow M, Vu VD, Hoang VS, Khou E. Newman M. 2017. Dipterocarpus gracilis, (B1). The IUCN Red List of Threatened Species 2017:
E.T31315A2804348. DOI 3.RLTS.T31315A2804348.en.

Lynch M, Conery J, Burger R. 1995. Mutation accumulation and the extinction of small populations. Am Nat 146 (4): 489-518. DOI: $10.1086 / 285812$

Millet J, Tran N, Vien Ngoc N, Tran Thi T, Prat D. 2013. Enrichment planting of native species for biodiversity conservation in a logged tree plantation in Vietnam. New For 44 (3): 369-383. DOI: 10.1007/s11056-012-9344-6

Nei M. 1987. Molecular Evolutionary Genetics. Columbia University Press, New York.

Ng CH, Lee SL, Tnah LH, Ng KKS, Lee CT, Diway B, Khoo E. 2019. Genetic diversity and demographic history of an upper hill dipterocarp (Shorea platyclados): Implications for conservation. J Hered 110 (7): 844-856. DOI: 10.1093/jhered/esz052

Oakley CG, Winn AA. 2012. Effects of population size and isolation on heterosis, mean fitness, and inbreeding depression in a perennial plant. New Phytol 196 (1): 261-70. DOI: 10.1111/j.14698137.2012.04240.x. Epub 2012 Jul 23. PMID: 22816555.

Pavlova A, Beheregaray LB, Coleman R, Gilligan D, Harrisson KA, Ingram BA, Kearns J, Lamb AM, Lintermans M, Lyon J, Nguyen TTT, Sasaki M, Tonkin Z, Yen JDL, Sunnucks P. 2017. Severe consequences of habitat fragmentation on genetic diversity of an endangered Australian freshwater fish: A call for assisted gene flow. Evol Appl 10 (6): 531-550. DOI: 10.1111/eva.12484.

Peakall R, Smouse PE. 2012. GenALEx 6.5: Genetic analysis in Excel. Population genetic software for teaching and research-an update. Bioinformatics 28(19) : 2537-2539. DOI: 10.1093/bioinformatics/bts460

Pekkala N, Knott KE, Kotiaho JS, Nissinen K, Puurtinen M. 2014. The effect of inbreeding rate on fitness, inbreeding depression and heterosis over a range of inbreeding coefficients. Evol Appl 7 (9): 1107-1119. DOI: 10.1111/eva.12145.

Ralls K, Ballou JD, Dudash MR, Eldridge MDB, Fenster CB, Lacy RC, Sunnucks P, Frankham R. 2018. Call for a paradigm shift in the genetic management of fragmented populations. Conserv Lett 11 (2): 1-6. DOI: $10.1111 /$ conl.12412.

Ratnam W, Rajora OP, Finkeldey R, Aravanopoulos F, Bouvet JM, Vaillancourt RE, Kanashiro M, Fady B, Tomita M, Vinson C. 2014. Genetic effects of forest management practices: Global synthesis and perspectives. For Ecol Manag 333: 52-65. DOI: 10.1016/j.foreco.2014.06.008.

Ratnaningrum YWN, Indrioko S, Faridah E, Syahbuddin A. 2015. The effects of population size on genetic parameters and mating system of sandalwood in Gunung Sewu, Indonesia. Indon J Biotechnol 20 (2): 182-201.

Ratnaningrum YWN, Indrioko S, Faridah E, Syahbudin A. 2017. Gene flow and selection evidence of sandalwood (Santalum album) under various population structures in Gunung Sewu (Java, Indonesia), and its effects on genetic differentiation. Biodiversitas 18 (4): 1493-1505. DOI: 10.13057/biodiv/d180428

Reynolds G, Payne J, Sinun W, Mosigil G, Walsh RPD. 2011. Changes in forest land use and management in Sabah, Malaysian Borneo, 19902010, with a focus on the Danum Valley region. Phil Trans R Soc B 366: 3168-3176. DOI: 10.1098/rstb.2011.0154

Sasaki S. 2006. Ecology and Physiology of Dipterocarpaceae. In: Suzuki K, Ishii K, Sakurai S, Sasaki S (eds). Plantation Technology in Tropical Forest Science. Springer, Tokyo. DOI: 10.1007/4-431-28054-5_1

Sgrò CM, Lowe AJ, Hoffmann AA. 2011. Building evolutionary resilience for conserving biodiversity under climate change. Evol Appl 4 (2): 326-337. DOI: 10.1111/j.1752-4571.2010.00157.x.

Slatkin, M. 1987. Gene flow and the geographic structure of natural populations. Science 236: 787-792. DOI: 10.1126/science.3576198.

Smith JR, Bagchi R, Ellens J, Kettle CJ, Burslem DFRP, Maycock CR, Khoo E, Ghazoul J. 2015. Predicting dispersal of auto-gyrating fruit in tropical trees: A case study from the Dipterocarpaceae. Ecol Evol 5 (9): 1794-1801. DOI: 10.1002/ece3.1469.

Seido K. 1993. Manual of Isozyme Analysis. JICA and Directorate General of Reforestation and Land Rehabilitation. Ministry of Forestry in Indonesia, Jakarta.

Star B, Spencer HG. 2013. Effects of genetic drift and gene flow on the selective maintenance of genetic variation. Genetics 194 (1): 235244. DOI: 10.1534/genetics.113.149781

Tam NM, Duy VD, Duc NM, Giap VD, Xuan BTT. 2014. Genetic variation in and spatial structure of natural populations of 
Dipterocarpus alatus (Dipterocarpaceae) determined using single sequence repeat markers. Genet Mol Res 13 (3): 5378-5386. DOI: 10.4238/2014.July.24.17

Tani N, Tsumura Y, Fukasawa K, Kado T, Taguchi Y, Lee SL, Lee CT, Muhammad N, Niiyama K, Otani T, Yagihashi T, Ripin A, Kassim AR. 2012. Male fecundity and pollen dispersal in hill dipterocarps: Significance of mass synchronized flowering and implications for conservation. J Ecol 100 (2): 405-415. DOI: 10.1111/j.13652745.2011.01929.x

Tito de Morais C, Ghazoul J, Maycock CR, Bagchi R, Burslem DFRP, Khoo E, Itoh A, Nanami S, Matsuyama S, Finger A, Ismail SA, Kettle CJ. 2015. Understanding local patterns of genetic diversity in dipterocarps using a multi-site, multi-species approach: Implications for forest management and restoration. For Ecol Manag 356: 153165. DOI: 10.1016/j.foreco.2015.07.023.

Tsumura Y. 2011. Gene flow, mating systems, and inbreeding depression in natural populations of tropical trees. In: Wickneswari R., Cannon C (eds) Managing the Future of Southeast Asia's Valuable Tropical Rainforests. Advances in Asian Human-Environmental Research. Springer, Dordrecht.

Utomo S, Uchiyama K, Ueno S, Matsumoto A, Widiyatno, Indrioko S, Na'iem M, Tsumura Y. 2018. Effects of Pleistocene climate change on genetic structure and diversity of Shorea macrophylla in
Kalimantan Rainforest. Tree Genet Genomes 14 (4). DOI: 10.1007/s11295-018-1261-1

Widiyatno, Hidayati F, Hardiwinoto S, Indrioko S, Purnomo S, Jatmoko, Tani N, Naiem, M. 2020. Selection of dipterocarp species for enrichment planting in a secondary tropical rainforest. Forest Sci Technol 16 (4): 206-215. DOI: 10.1080/21580103.2020.1831620.

Widiyatno, Indrioko S, Na'iem M, Purnomo S, Hosaka T, Uchiyama K, Tani N, Numata S, Matsumoto A, Tsumura Y. 2017. Effects of logging rotation in a lowland dipterocarp forest on mating system and gene flow in Shorea parvifolia. Tree Genet Genomes 13 (4). DOI: 10.1007/s11295-017-1167-3

Widiyatno, Indrioko S, Na'iem M, Uchiyama K, Numata S, Ohtani M, Matsumoto A, Tsumura Y. 2016. Effects of different silvicultural systems on the genetic diversity of Shorea parvifolia populations in the tropical rainforest of Southeast Asia. Tree Genet Genomes 12 (4). DOI: $10.1007 / \mathrm{s} 11295-016-1030-y$

Yeh FC, Boyle T, Rongcai Y, Ye Z, CXian, J. M. 1999. POPGENE, version 1.31. A Microsoft Window Based Freeware for Population Genetic Analysis. Molecular Biology and Biotechnology Centre, University of Alberta: Edmonton, AB, Canada. 